Check for updates

Newcastle upon Tyne

stokel@gmail.com

Cite this as: BMJ 2021;374:n2165 http://dx.doi.org/10.1136/bmj.n2165 Published: 20 September 2021

\title{
The search for antivirals for covid-19
}

\section{Antivirals are one of the most sought after, yet missing, tools to control SARS-COV-2. Chris Stokel-Walker asks what was learnt from a similar search nearly 20 years ago}

\section{Chris Stokel-Walker freelance journalist}

Antiviral drugs are among the most researched tools for treating covid-19. They either prevent a virus entering a host cell or prevent it from being able to replicate once it is inside.

And yet, over 18 months into the pandemic, finding ones that are effective against SARS-CoV-2 has proved challenging. Remdesivir was an early frontrunner-and many governments were desperate enough to grant it emergency use approval despite limited evidence.

Those early hopes were ultimately dashed when major studies, notably the World Health Organization's Solidarity trial, found it to be ineffective at preventing death (although it did help patients already recovering do so marginally faster). ${ }^{1}$ Doctors in Japan have treated covid-19 patients with favipiravir, an influenza antiviral, but the drug has previously been linked to birth defects. ${ }^{2}$

Developing antivirals is tricky-the first was approved only in 1963. Unlike antibiotics, which some bacteria make to combat other bacteria, few antivirals exist in nature. Viruses are also harder to target than bacteria (box 1).

Box 1: How an antiviral for covid-19 could work

Antivirals could tackle SARS-CoV-2 in several ways. To stop the virus entering the cell, any antiviral drug has to target two receptors on the virus: ACE-2 and TMPRSS2, says Ruth McKernan, chair of the Biolndustry Association, a trade body representing the industry.

Another route involves targeting the protein synthesis pathways, preventing the new viral proteins from being made. This could also be achieved by disabling the enzymes that split and reassemble immature viral proteins as they are being made. However, coronaviruses usually have a second layer of protein that checks and disposes of malfunctioning enzymes, and this layer could scupper efforts to use this route.

Finally, you could try interfering with RNA synthesis, again preventing the proteins from being made in the first place.

In terms of how an antiviral drug would be administered, McKernan believes an oral formulation like a tablet is likely to be the quickest, but least efficacious, route to achieving the UK taskforce's target-an antiviral by the end of the year-with other routes following later. Although oral drugs are the easiest and quickest to produce, for a disease like covid-19, which attacks the lungs, an inhaled drug would provide the greatest exposure at the point it's most needed. "Ultimately, giving a drug intravenously or in an inhaled way would be a very good way to go," McKernan says. This thinking is demonstrated by Gilead, the company that developed remdesivir and is pursuing an inhaled form of the drug.
On 28 May, the UK government announced a new antivirals taskforce aiming to bring antiviral treatments to the point of deployment in the UK by autumn 2021. ${ }^{3} \mathrm{~A}$ few weeks later, the US government also pledged \$3.2bn (£2.3bn; €2.7bn) to develop a new antiviral programme for covid-19. ${ }^{4}$

"The antiviral programme, and the story around antivirals, is an important one," says Eddie Gray, who chairs the UK taskforce, "It has a real contribution to make to the overall response of covid."

\section{Just little bits of history repeating}

They aren't starting from scratch. The UK taskforce has already recommended three previously investigated drugs be taken forward: favipiravir; iota carrageenan, a seaweed derivative that has been tested against other respiratory viruses ${ }^{5}$; and niclosamide, currently used to treat tapeworms. ${ }^{6}$

But perhaps the most information has come from study of SARS-CoV-2's predecessor.

In the early 20oos, an outbreak of severe acute respiratory syndrome (SARS), the disease caused by the coronavirus SARS-CoV-1, killed 774 people, predominantly in Asia. The quest for antivirals for SARS ultimately fizzled out with that epidemic. Motivation, and crucially funding, for the research effort ebbed away along with it. To date there are still no antivirals against SARS in clinical use, although a few remain in testing.

"A lot of the countries that were involved in SARS really saw [treatments for it] as a thing of importance, and we [in the west] didn't," says Christophe Fraser, an epidemiologist at the University of Oxford's Big Data Institute. The political consensus was that it was "a bit of a fuss about nothing."

The case was further damaged by ultimately false alarms around flu epidemics. The overordering of antivirals such as oseltamivir (Tamiflu) by governments in the mid-200os-the UK spent around $£ 473 \mathrm{~m}^{7}$-tainted belief in the importance of antivirals for the covid-19 pandemic, to medicine and humanity's detriment.

As political will disappeared so did drug development. Even the alarm over the Middle Eastern respiratory syndrome (MERS), which has killed 885 people since 2012, did not change priorities enough to bump antivirals up the drug development chain.

"I guess we just didn't get a signal from MERS to make it financially worthwhile," says Peter Wark of the University of Newcastle, Australia. The fact MERS was localised in one part of the world, and had a relatively low death count before fizzling out, meant 
decision makers thought it wasn't worth devoting precious resources to.

Now that SARS-CoV-2 is with us, those decisions have left us trying to catch up on lost time, says Wark. "If we had been more prescient back then and kept going, we clearly would have been in a better place than we are now," he says.

\section{Back to the future}

“There are very important lessons to learn from SARS-CoV-1," says Daria Hazuda, vice president of research and chief scientific officer at MSD (Merck), which is working to develop antivirals. And those abandoned pathways can still be built on.

Work on the structure of SARS-CoV-1 in the early 2000 s was repurposed in the covid pandemic. For one thing, the analysis helped speed up vaccine development by providing easily mappable structures of the spike protein that needed to be targeted. "That work has been, I think, instrumental in moving the field forward," says Hazuda. MSD is among those developing covid-19 antiviral candidate drugs, including molnupiravir, which is currently in phase III trials with outpatients (testing in patients admitted to hospital with covid-19 has been halted because it is unlikely to be successful, perhaps because of the duration of their symptoms, say MSD) .8

"History has helped us," says Wark, "Some of that earlier work wasn't completely lost." In terms of antivirals, Pfizer for one, has developed new antivirals against SARS-COV-2 based on a protease inhibitor developed in response to the original SARS virus.

Saye Khoo, professor of pharmacology and therapeutics at the University of Liverpool, hopes we have learnt the value of continuing and investing in these studies even when the threat diminishes.

"There's a lot of drug development you can do in peacetime ahead of any outbreak," says Khoo, who leads the Agile Coronavirus Drug Testing Initiative, which evaluates the effectiveness of new treatment candidates, including antivirals and monoclonal antibodies. ${ }^{9}$ Among the drugs they are testing are molnupiravir and nitazoxanide, an antiparasitic drug.

"Conventional drug development simply wasn't designed for a pandemic. It wasn't fast enough," he says, "I hope coming out of this pandemic, we'll be in a much better place should the next one be just around the corner."

There is a model for hope in the recent past: 40 years ago when the HIV epidemic hit, the world had no antivirals against this new threat. But the urgency ultimately led to a flourishing market, which has helped make HIV/AIDS a liveable condition.

Covid-19 could do similar. Says Wark, "I would hope this is a bit of a game changer for the area, with regard to viruses, and respiratory viruses particularly."

Competing interests: I have read and understood BMJ policy on declaration of interests and have no relevant interests to declare.

Provenance and peer review: Commissioned; externally peer reviewed.

Hsu J. Covid-19: What now for remdesivir?BM/2020;371:m4457 doi: 10.1136/bmj.m4457 pmid: 33214186

2 This drug may cause birth defects. Japan's pushing it for coronavirus. New York Times 2020 May 5. https://www.nytimes.com/2020/05/05/business/japan-avigan-coronavirus.html

3 Department of Health and Social Care. Eddie Gray appointed chair of antivirals taskforce. Press release, 28 May 2021. https://www.gov.uk/government/news/eddie-gray-appointed-chair-ofantivirals-taskforce
4 Watch: Fauci says US to spend \$3.2 billion on antiviral pills for COVID-19. PBS News Hour, 17 Jun 2021. https://www.pbs.org/newshour/politics/watch-live-white-house-covid-task-force-holdsnews-briefing-4

5 Eccles R, Winther B, Johnston SL, Robinson P, Trampisch M, Koelsch S. Efficacy and safety of iota-carrageenan nasal spray versus placebo in early treatment of the common cold in adults: the ICICC trial. Respir Res 2015;16:121. doi: 10.1186/s12931-015-0281-8 pmid: 26438038

6 UK Research and Innovation. Outcomes of the UK covid-19 therapeutics advisory panel (UK-CTAP) [REMOVED IF= FIELD]https://www.ukri.org/about-us/policies-standards-and-data/data-collection/uk-covid-19-therapeutics-advisory-panel/recommended-treatments-for-clinical-trials/

7 Scientists say UK ministers wasted millions on flu medicine. Financial Times 2014 Apr 9. https://www.ft.com/content/2547c786-bff0-11e3-b6e8-00144feabdc0

8 Merck and Ridgeback. Biotherapeutics provide update on progress of clinical development program for molnupiravir, an investigational oral therapeutic for the treatment of mild-to-moderate covid-19. 2021. https://www.merck.com/news/merck-and-ridgeback-biotherapeutics-provideupdate-on-progress-of-clinical-development-program-for-molnupiravir-an-investigational-oraltherapeutic-for-the-treatment-of-mild-to-moderate-covid-19/

9 Agile Coronavirus Drug Testing Initiative. Two new therapies to be tested in ground-breaking COVID-19 clinical trial. Press release, 12 Jan 2021. https:/www.agiletrial.net/wp-content/uploads/2021/01/Agile-CST5-press-release-FINAL-11.01.21-1.pdf

This article is made freely available for use in accordance with BMJ's website terms and conditions for the duration of the covid-19 pandemic or until otherwise determined by BMJ. You may use, download and print the article for any lawful, non-commercial purpose (including text and data mining) provided that all copyright notices and trade marks are retained. 